Sources, Materials, Miscellanea

http://dx.doi.org/10.15762/ZH.2018.21

JOANNA ORZEE

(University of Lodz)

STANISEAW ROSZAK

(Nicolaus Copernicus University in Toruń)

\title{
Letters of Piotr Hiacynt Śliwicki to the Papal Nuncio Alberico Archinto from the Years 1754-1757 in the Collections of the Vatican Archive*
}

Key words: correspondence of the $18^{\text {th }}$ century, the assembly of missionaries, the conflict about tithes of 1752-1753, Teodor Kazimierz Czartoryski, the seminary in Krasław, Protestant in Warsaw in the $18^{\text {th }}$ century, nunciature in the Polish-Lithuanian Commonwealth in the $18^{\text {th }}$ century

The correspondence from the period of the Polish-Lithuanian Commonwealth is to be found in many European archives and libraries. Letters which interest us are kept in Archivum Secretum Vaticanum, in the collection Segreteria di Stato, Polonia. Among the sources included in the collection there is a complex "Additamenta Polonia", where, under entry no. 11 there is a section "Lettere diverse" - letters to various people. The collection includes the correspondence of the suffragan bishop of Lviv Samuel Głowiński (1703-1776), the bishop of Poznań Teodor Kazimierz Czartoryski (1704-1768) and the bishop of Smoleńsk Jerzy Mikołaj Hylzen (1692-1775). Nevertheless, our attention was drawn to three letters written by Piotr Hiacynt (Jacek) Śliwicki, which we enclose in the annex at the end of the article. Two of them come from 1754, one from 1757. So far we have not confirmed that scholars are familiar with this correspondence.

Piotr Hiacynt (Jacek) Śliwicki was born on 3 July 1705. He was educated in the Warsaw College of Theatines. In 1721 he joined the seminary of the Congregation of Missionary Priests in the Church of the Holy Cross. He studied there philosophy and theology. He took monastic vows on 4 July 1723 , and took holy orders on 28 October 1728 . From 1730 he held the office of the

* The article was created thanks to the scholarship for co-author of this text Joanna Orzeł funded by the Fundacja Lanckorońskich [Lanckoronski Foundation]. 
prosecutor of the Polish province of the congregation of missionaries, which allowed him to travel and to maintain rich correspondence. He was the confessor of king August II on his deathbed. Stanisław Leszczyński appointed him to be the royal preacher; he was occasionally a confessor of king August III and Stanisław August. In 1739 he became the general provincial. He appreciated missionary activities. He also held the function of the religious censor of published books. Despite the fact that in 1763 he stopped holding the office of the parson and the superior of the monastery, he continued to be the inspector; additionally, he supervised the charity activity of the missionaries. He died on 5 May $1774^{1}$.

The addressee of the letters presented here written by P. H. Śliwicki is Alberico Archinto, the papal nuncio in the Polish-Lithuanian Commonwealth in the years 1746-1754. He was an experienced official and diplomat; he had a doctor's degree in Law, which he had obtained at the University of Pavia. From 1724 he worked in the Roman Curia as Protonotary Apostolic, the justiciary of the Supreme Tribunal of the Apostolic Signatura (the highest judicial authority), later in the papal diplomacy in Tuscany and in the Polish-Lithuanian Commonwealth. His uncle was the papal nuncio in the Polish-Lithuanian Commonwealth in the years 1720-1721 Girolamo Archinto. In 1739 he was appointed archbishop of Nice. After his mission in the Polish-Lithuanian Commonwealth finished, he returned to Italy (on 12 March 1754$)^{2}$, where took the office of the governor of Rome, and next, after the death of Silvio Gonzaga, Pope Benedict XIV appointed him the secretary of the state of the Holy See. The end of his career was crowned by his receiving the title of the vicechancellor of the Roman Catholic Church; he held this office until his death on 30 April 1758.

Letters of Piotr Hiacynt Śliwicki to the nuncio Alberico Archinto are the evidence of the long-lasting acquaintance and cooperation of both dignitaries of the Church. The missionary as the general inspector (provincial) taking care of the development of his congregation maintained good relations

${ }^{1}$ The biographical profile on the basis of: Zofia Zielińska, Śliwicki Piotr Hiacynt (Jacek), [in:] Polski słownik biograficzny, t. 50/4, Warszawa-Kraków 2015, pp. 586-591.

${ }^{2}$ The date 12 February 1754 as the time to finish the mission is provided by the dictionary: Salvador Miranda, The Cardinals of the Holy Roman Church. Biographical Dictionary, chapter Pope Benedict XIV (1740-1758), p. 57 http://www2.fiu.edu/ mirandas/bios1756.htm\#Archinto (accessed December 20,2017). On the other hand, Henryk Damian Wojtyska CP provides the date 25 June 1754 as the time of leaving Dresden and completing the mission by A. Archinto, see: Acta Nuntiaturae Poloniae, t. 1, Romae 1990, p. 309. The same date is provided in Repertorium der diplomatischen Vertreter aller Länder, t. 2, ed. Friedrich Hausmann, Zürich 1950, p. 264. It seems that in the light of the letters of Piotr Hiacynt Śliwicki it is the first date that should be considered to be the day of his departure from Warsaw. 
with the papal nuncio and the Roman Curia. As early as the 1730s he became known as the successful administrator of the Polish province and as the unquestioned authority in the issues concerning the Catholic faith. As a lecturer of moral theology in the Warsaw seminary he cared about doctrinal purity; he carefully observed his new professor from France - potential intermediaries in the process of transferring the Gallican and Jansenist ideas to the PolishLithuanian Commonwealth. In one of the letters, written on 13 September 1730, he revealed his alertness: "I shall keep an eye on new professors so that they should not teach novitates in theology; however, I have observed in the conversation that they have good sentiments and specific circa Pontificem; anticonstitutionarios abhorrent as the Calvinists"3 [trans. Agnieszka Chabros].

The expert in theology, fluent in many languages, won recognition in the field of respublica litteraria, and consolidated his authority among dignitaries of the Church. He was consulted in issues concerning the edition and translation of religious works. It was often him who decided whether a given book was in accordance with the doctrine and deserved to be published. However, in his opinions he was open to new, enriching novelties (novitates) from the West, including the Protestant ones. He was capable of dividing the issues of theological disputes and threats to the faith from real erudition. This attitude was close to the trend of humanistic erudition, which was still valid in the $18^{\text {th }}$ century. According to this trend, the scholar was a polyhistorian, moralist, rhetorician, expert in foreign languages. As has been emphasized by Wiesław Pawlak, the erudite treated knowledge as the "tool of the moral and religious development of man and an important element of the civilian humanitas, which, according to the Ciceronian tradition, obliged people to work for the benefit of the Polish-Lithuanian Commonwealth and the Church" ${ }^{\prime 4}$ [trans. A.C.]. The only thing which could be added here is that in the case of Piotr Hiacynt Sliwicki it was the work done for the benefit of the Church and the state, but it also contributed to the development of the community of scholars. His interpretation which he formulated at the beginning of his career and which accompanied him to the end of the cooperation within the republic of scholars, is the evidence of his attitude to academic creativity and its confrontation with the Catholic faith - mainly with the purity of the Catholic teaching. In the discussion about censorship with his friend from Vilnius - Józef Stanisław Sapieha - he underlined that scientific works (referring to history, politics, art and science) which did not constitute the discourse of pure polemical or dogmatic

${ }^{3}$ Cited after: W. Szymbor, Trzy lata w życiu ks. Śliwickiego 1732-1734, Roczniki Obydwóch Zgromadzeń Św. Wincentego a Paulo, R. 15: 1909, nr 4, p. 252.

${ }^{4}$ Wiesław PaWlak, De eruditione comparanda in humaniorubus. Studia $z$ dziejów erudycji humanistycznej w XVII wieku, Lublin 2012, p. 126. 
theology deserved to be published despite including some content against the Catholic faith. Only works which did not fulfil the first condition should be banned exprofesso $0^{5}$.

In the entourage of scholars Piotr Hiacynt Śliwicki was considered to be an erudite, expert in foreign languages, literature, theology, the evidence of which is not only his correspondence, but also the cooperation with Józef Andrzej Załuski, Józef Stanisław Sapieha, Józef Aleksander Jabłonowski, Jerzy Mikołaj Hylzen, along with the fact of his name being included in the dictionary of scholars of Jan Daniel Janocki. The librarian of the Załuski Library, outlining the scientific profile of the missionary, emphasized his activity in the discussion of respublica litteraria and in the Public Library: "allwo er sich mit dem Canonico Janozki von den merkwürdigsten Büchern und sonderbarsten Entdeckungen der Gelehrten unterredet..."'. Śliwicki used the collections of the Library borrowing books necessary for his scientific work. In January 1748 he asked J. A. Załuski to lend him the Latin edition of the works of Vergila and Horace along with the Greek and Latin edition of the history of Herodotus?

This description of Piotr Hiacynt Śliwicki's attitude as the representative of the Church on the one hand, and the active representative of the world of respublica litteraria seems to be indispensable for the understanding of viewpoints which the missionary reveals in his letter to the papal nuncio.

The first question here is the conflict concerning the tithe, which spread all over the Polish-Lithuanian Commonwealth in the years 1752-1753. Noblemen of Masovia started to struggle with clergymen, who insisted on their right to collect the tithe. The noblemen discredited the sentences of the consistory court issued in reference to representatives of the nobility since they considered land courts to be the only legitimate bodies to adjudicate in cases concerning noblemen. The noblemen were supported by the grand crown marshal Franciszek Bieliński, who was brought to the consistory court in February 1752 for not paying the tithe from his Masovian estates. The polemic fever pervaded the whole country. Noblemen's appeals to resist the greed of the clergy triggered counter-appeals which referred to the decisions of the Council

${ }^{5}$ The letter of Piotr Hiacynt Śliwicki to Józef Stanisław Sapieha of 7 March 1733, Lietuvos mokslu akademijos Vrublevskių bibliotekos [The Wroblewski Library of The Lithuanian Academy of Science] (further cit. LMAVB), F139-4239/2: "De ce principe général qui sétend loin vous pouvez insérer, Monseigneur, qu'un livre qui contient des lettres ou d'autres matières indifférentes ne doit pas être censé tractans ex professo à cause quon trouve là dedans une ou deux lettres, un ou deux chapitres qui impugnent notre foi".

${ }^{6}$ Jan Daniel Janocki, Lexicon derer itzlebenden Gelehrten in Polen, t. 1, Breslau 1755, p. 156.

${ }^{7}$ Letter of Piotr Hiacynt Śliwicki to Józef Andrzej Załuski of 19 Jan 1748, Biblioteka Narodowa [The National Library of Poland] (further cit. BN), manuscript III 3248. 
of Trent, and even to the Holy Scriptures. The pamphlet of the French monk Vivien de la Borde became very popular. He argued there that the clerical authority should be subordinated to the secular authority in public matters. In the light of his reasoning, the clerical authority could control only internal issues of the Church and religion. The book was published in 1753 in the French original version; it was translated to Polish ${ }^{8}$. The marshal, seeing the support of noblemen, insisted on the power of the consistory courts being limited. $\mathrm{He}$ indicated the expertise of secular courts not only in the matters concerning the tithe, but also in conflicts concerning the boundaries of estates, nuns' dowry, conflicts concerning fugitives, etc. ${ }^{9}$ Requests to increase the jurisdiction of secular courts were recorded in the letter of 15 May 1753 titled Punkta propozycji przystane przy liście JWJMci Pana Marszałka W. Koronnego sub datum 15 Mai $z$ Otwocka do Prymasa oraz annotacje ${ }^{10}$.

Interestingly, the Vincentian monk underlined in his account to the nuncio that the activities of marshal Bieliński were neither the attack against the Church nor the nunciature. In fact, they were the expression of his political activity, which was to provide him popularity („d'une entreprise par laquelle il se flatte d'immortaliser son nom et d'acquérir la réputation de grand homme"). That is why, to his way of thinking, the marshal exaggerated in his letters the affluence of the clergy and its dominance over noblemen. It would confirm the thesis that F. Bieliński was faced with the conflict with the clergy having been moved into the political shadows by the leader of the courtly party Jerzy August Mniszch. Bieliński attempted to use the conflict about the tithe as a kind of political trampoline ${ }^{11}$. It should be added here that he was not the only one to do so. The bishop of Cracow Andrzej Stanisław Załuski tried to talk his brother - the crown referendary looking for a profitable position - into joining the discussion about the role of the clergy in the Polish-Lithuanian Commonwealth, "pour immortaliser votre nom"12, which sounds like an extract from Śliwicki's opinion about the motifs of the marshal's actions. The younger brother Józef Andrzej Załuski was to consult the content of his letter with the

${ }^{8}$ Principes sur l'essence, la distinction et les limites des deux puissances spirituelle et temporelle, [s.l.] 1753, the Polish version: Nauki o istocie, różnicy i granicach dwóch władz, to jest $d u$ chownej i świeckiej, [s.l.] 1753.

${ }^{9}$ Władysław Smoleński, Przewrót umysłowy w Polsce wieku XVIII. Studia historyczne, ed. Andrzej WierzBicki, Warszawa 1979, pp. 300-302.

${ }^{10}$ Karol Estreicher, Bibliografia polska, t. 9: Spis chronologiczny, Kraków 1888, p. 250.

${ }^{11}$ Helena Waniczkówna, Bieliński Franciszek, [in:] Polski słownik biograficzny, t. 2, Kraków 1936, p. 48.

${ }^{12}$ Letter from Andrzej Stanisław Załuski to Józef Andrzej Załuski of 11 March 1753, BN, manuscript III 3253. 
primate: "The beautiful area opens up, où vous pourriez briller in the dispute of laymen about clergymen, il faudrait se saisir de cette occasion pour immortaliser votre nom and in Rome parare gradum pro immunitate Ecclesiae zelando et scribendo, but non sine consilio et assensu of the primate" [trans. Agnieszka Chabros]. A month later he asked the papal nuncio to contact him about this issue; he insisted that he remain anonymous in the event of the publication $^{13}$.

The issue that drew the attention of the missionary and was inscribed in his supervisory function over religious and moral life, was the analysis of activities and behaviours of the clergy, with particular emphasis on the role of bishops in the management of dioceses and their moral comportment. Śliwicki's priorities included the maintenance of the purity of the doctrine, the execution of the decisions of the Council of Trent, the strengthening of the mission and the education of clergymen. Throughout all the time of his activity, the missionary cared for proper moral standards for the clergy; he observed and castigated abuses as he saw in them the threat to the public opinion. A case in point here may be his criticism of the new "sensual" custom of celebrating the carnival in Warsaw, on the frozen Vistula River, following the Venetian fashion - "en imitatant ceus de Venise"14, or his concern about abstinence in mission homes, which referred mainly to the consumption of alcohol ${ }^{15}$.

In his letters of 20 March and 6 April, the Lazarist described to the nuncio the situation at the court of the bishop of Poznan Teodor Kazimierz Czartoryski, which, according to him, put at risk the proper fulfilment of pastoral duties; what is more, the fact of the bishop's being surrounded by the Lutherans could provoke umbrage among Catholics. The inspector accused the bishop of visiting Warsaw too rarely and staying too much time in Greater Poland and this part of the diocese. The description of the bishop's behaviour revealed his worldly lifestyle, his love of conversations, art, music and hunting, which reduced his interests in the affairs of the diocese. The picture of the bishop shown in the letters confirms the opinions of his contemporaries, "who considered him to be a trifler, able only to talk about freedoms and public welfare,

${ }^{13}$ Letter from Andrzej Stanisław Załuski to Józef Andrzej Załuski of 8 April 1753, BN, manuscript III 3253.

${ }^{14}$ Letter from Piotr Hiacynt Śliwicki to Józef Stanisław Sapieha of 19 February 1751, Archiwum Główne Akt Dawnych [The Central Archives of Historical Records in Warsaw] (further cit. AGAD), Zbiór Czołowskiego, sygn. 584.

${ }^{15}$ Letter from Piotr Hiacynt Śliwicki to the superior of the missionaries Śmiłowicze of 28 November 1768, LMAVB, F7-2219: "If there is something that may ruin our assembly in this country it is this drink [alcohol]. Heaven forbid! I am in his holy love" [trans. A.C.]. 
but unable to work hard, not really decent in his private life and having some

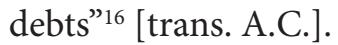

On the other hand, the missionary defended the bishop, refuting the allegation concerning the bishop's supposed permission for the Lutheran rite in the capital. Despite the concern generated by the presence of Lutherans at the court of the bishop, Śliwicki explained that critical comments concerning the support for the public Lutheran funeral in Warsaw were unfairly directed against Czartoryski. The problem referred to the funeral of the Lutheran, architect and general major Carl Friedrich von Pöppelmann (he was the son of the well known architect of Dresden Matthäus Daniel Pöppelmann) and the permission for the funeral procession in Warsaw in 1750. The event gave rise to public outrage and caused the reaction of the royal court despite the fact that the funeral took place without the presence of Lutheran priests, but with the military honours. Jędrzej Kitowicz gives an account of this event underlining the sumptuousness of the ceremony: "The first time in Warsaw in our century we have seen a public Lutheran funeral. It was the funeral of the Saxon general Pepelmann, whose body was transported, on a high funeral carriage harnessed to six horses covered with funeral robes, from Marywil to Leszno, where dissidents had their cemetery without a church. Five hundred soldiers of the crown infantry guards accompanied the funeral; they were followed by 200 horse-riding soldiers from the regiment of Brühl; the coffin was followed by 12 cannons with several dozens of cannon founders from the crown

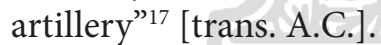

We should remember that the celebration of public holy services by dissidents continued to be forbidden (on the strength of the constitution of the Silent Sejm of 1717), and religious ceremonies were organized exclusively in the home chapel of Prussian diplomats ${ }^{18}$. In the register Laesiones praw publicznych, which circulated as manuscript copies, there appeared a complaint that the King favours foreigners and allows dissidents to organize public holy services in the capital: "Free (unhindered) confession of faith in Warsaw by non-Catholics is a scandalous thing against the law of the Polish-Lithuanian Commonwealth and the law of the Masovian Duchy. It is necessary to get bish-

${ }^{16}$ Władysław KonopczyŃski, Teodor Kazimierz Czartoryski, http://www.ipsb.nina.gov.pl/ a/biografia/teodor-kazimierz-czartoryski (accessed December 20, 2017).

${ }^{17}$ Jędrzej Kitowicz, Pamiętniki czyli Historia polska, ed. Przemysława Matuszewska, Warszawa 1971, pp. 53-54.

${ }^{18}$ About the legal situation of Protestants in the Saxon Times comp. Wojciech KRIEGSEISEN, Ewangelicy polscy i litewscy w epoce saskiej (1696-1763). Sytuacja prawna, organizacja $i$ stosunki międzywyznaniowe, Warszawa 1996. 
ops to stop these frequent meetings [it refers to meetings of non-Catholics Protestants - S.R.]; it should be like in other countries, where everyone prays at home in silence and without sermons, along with their family and without the presence of strangers, which is also observed by foreign ministers in Catholic countries; for this (that in Warsaw there takes place a public confession of faith by non-Catholics) God punishes the Polish-Lithuanian Commonwealth with plagues inside and outside the country and allows public funerals of Protestants, as it was in the case of Mr. Pepelman's funeral"19 [trans. A.C.].

This event was also recorded by the chronicler of the Piarists of Warsaw, who in 1750 wrote down that the funeral of the Lutheran Pöpelmann in Warsaw took place doing irreparable harm to the Catholic faith and causing incredible outrage "among people of both sexes and every single social class". According to him, the permission for the funeral was not issued by the bishop, but by one of his officials ${ }^{20}$. This version was also confirmed by Sliwicki, who pointed out that the Warsaw official Antoni Grzegorzewski had issued a permission for the funeral and had taken money for the service without the knowledge and approval of the bishop Czartoryski, which eventually led to his being dismissed.

The problem which arose in the context of the evaluation of the Poznan bishop's performance in the diocese was connected with the bookshop in Warsaw in Marywil. The missionary warned against the development of this bookshop as it was to sell books which were pernicious to the Catholic faith. What is worse, the bishop's attempt to intervene was unsuccessful as the bookshop was supported by the royal court. Marywil - the commercial centre established upon the initiative of queen Maria Kazimiera at the end of the $17^{\text {th }}$ century - in the mid- $18^{\text {th }}$ century constituted an important place of the activity of craftsmen and merchants. It was there that the activity of Lutheran burghers concentrated $^{21}$.

The bookshop was a branch of the well known company of Leipzig, and from 1743 after the death of Weidmann it became an independent shop. Its owner was Krzysztof Bogumił Nicolai ${ }^{22}$. He enjoyed the recognition of erudite

${ }^{19}$ Laesiones praw publicznych, AGAD, Archiwum Radziwiłłów, dz. II, ks. 46, k. 33.

${ }^{20}$ Historia Domus Varsaviensis Scholarum Piarum, oprac. Ludwik Chмај, Wrocław 1959, s. 46: "Eodem anno m. Aprili cum summo religionis cathol. Praeiudicio publice eductum est cadaver lutherani Pepelman ad locum sepulturae extra civitatem Varsaviensem. Quod indultum rvdissimi officialis omne prope sexum et ordinem incredibili affecit scandalo multumque offendit".

${ }^{21}$ Comp. Marta A. Kuc-Czerep, "Niemieckojęzyczni mieszkańcy osiemnastowiecznej Warszawy", the doctoral thesis supervised by W. Kriegseisen, Warszawa 2017 (a typescript of the doctoral thesis in the Library of the Institue of History Polish Academy of Sciences in Warsaw), p. 132.

${ }^{22}$ Jerzy Ratajewski, Nicolai Krzysztof Bogumił, [in:] Słownik pracowników ksiażki polskiej, red. Irena Treichel, Warszawa-Łodź 1972, s. 625. Comp. Lustracja Dawidsona, [in:] Źródła do 
persons of Warsaw. He published catalogues of Polish, Latin and French books. He was also the publisher of the works of Vergil. In view of all this, the missionary's sharp criticism towards the publisher should be surprising. It seems that the reason for the criticism was the concern about the purity of the Catholic faith and morality, triggered by reading the catalogue of books published by this bookseller in 1754 . The analysis of the catalogue might have generated some concern as Nicolai went beyond the book offer of his predecessor. In the catalogue he included e.g. the works of French philosophers: Voltaire, Montesquieu, Malebranche, the philosophical works of Wolff ${ }^{23}$. However, Śliwicki's concern was not entirely justified. Krzysztof Bogumił Nicolai in his catalogues offered a wide range of books believing that scholars, prepared to read and understand the works, would evaluate their content themselves. His offer was directed towards people who were prepared to read books which could be dangerous for religion and morality ${ }^{24}$.

In the third letter there appears a question which is particularly close to Śliwicki - the problem of strengthening the mission of Lazarists in Krasław [Kreslau]. The town situated in Polish Livonia, on the Daugava River is known as the site of the residence of the Plater family. Konstanty Ludwik Plater in the years 1755-1767 built here a church (expected to be the Livonian cathedral) and a house for the seminary. The suffragan bishop of Livonia was to reside there. The first rector and superior of the Krasław house was Paweł Szerbon'ski ${ }^{25}$. Missionaries took over the parish on 29 December 1755. As Agnieszka Wieczorek points out, "on the strength of the foundation act they were obliged to carry out their pastoral activity and mission in the estate of the Platers and in the Livonian diocese, to administer the hospital and the shelter for the poor, to take care of the chapel in the palace of the Plater family and to run the seminary"26 [trans. A.C.]. From 1711 the bishop Teodor Wolff de Ludingshausen prepared appropriate resources and the bishop of Smolensk Jerzy Mikołaj Hylzen donated 2,000 thalers so that clerics could also study in the seminary, which was opened in 1757 under the supervision of missionary priests from Warsaw. The Holy See, wanting to contribute to the development

dziejów Warszawy, t. 1, ed. Anna Berdecka, Janina Rutrowska, Anna Sucheni-Grabowska, Hanna Szwankowska, Warszawa 1963, p. 426, where K. B. Nicolai is presented as a dissident and book seller residing in Marywil.

${ }^{23}$ Catalogue des livres francois qui se trouvent chez Christophe Gottlieb Nicolai libraire a Varsovie, Varsovie 1754.

${ }^{24}$ Catalogus librorum latinorum qui prostant Varsaviae apud Ch. G. Nicolai Bibliopolam, 1754, Praefatio, pp. 3-4.

${ }^{25}$ Agnieszka Wieczorex, Misje ludowe Zgromadzenia Księży Misjonarzy św. Wincentego a Paulo na terenie Rzeczypospolitej od połowy XVII do początku XIX wieku, Toruń 2014, p. 105.

${ }^{26}$ Ibid. 
of the institution, offered 18 ducats $^{27}$ to maintain 5 alumni of the Smolensk diocese, or (should there be no alumni from Smolensk) from Livonia and Courland ${ }^{28}$. In the letter written from Krasław to Alberico Archinto of 24 October 1757, the bishop of Smolensk Hylzen described the condition of the new seminary in the town. He mentioned that in the foundation of Plater there was a well equipped congregation house - with good facilities for both spiritual and educational needs of young clerics. He stated that it would be possible to admit a bigger number of students on the condition that the Pope supported the seminary financially. The bishop of Smolensk assured that Sliwicki - as a provincial - would provide more details about $\mathrm{it}^{29}$.

Three days later Śliwicki in his letter to Archinto announced that he was in Krasław, where in the house of the earl Plater he had met the bishop of Smolensk. He said that the owner of Krasław had promised to build a solid and spacious seminary made of brick. In the meantime he erected a wooden building for missionaries and clerics. Focusing on financial matters, Śliwicki calculated that the earl had remunerated four missionaries, the bishop of Livonia had remunerated the professor of theology and four clerics, while the bishop of Smolensk - the second professor of theology and two clerics. He also underlined that in the Krasław house there were three missionaries, and others would arrive gradually. All the funds were collected, which allowed providing 21 ducats a year for the maintenance of clerics. The final target was the education of 12 clerics; that is why six clerics seemed too small a number for Sliwicki. He underlined that the major part of inhabitants of the Smolensk diocese were members of the Greek Orthodox Church, but there were also many inhabitants of the Latin rite, who should be looked after. In the end, Sliwicki emphasized that he felt obliged to provide all those details hoping the Pope to contribute financially.

trans. by Agnieszka Chabros

\section{Source Annex}

The text of the source was published as a whole, without any abbreviations. Spelling and punctuation was modernized. In case of doubts concerning the interpretation of the text the question mark [?] was used. The location of the information about the place and date of writing the letter was changed - in the

${ }^{27}$ Agnieszka Wieczorek mentions 180 ducats every year. Ibid.

${ }^{28}$ Krasław, [in:] Słownik geograficzno-historyczny Królestwa Polskiego i innych krajów słowiańskich, red. Filip Sulimierski, Bronisław Chlebowski, Władysław Walewski, t. 4, Warszawa 1885 , p. 617.

${ }^{29}$ Jerzy Mikołaj Hylzen to Alberico Archinto, Krasław, 24 X 1757, Archivum Secretum Vaticanum, Segr. Stato Polonia, Additamenta 11. 
original letter they were placed at the end of the letter. The names of the offices such "grand marechal", "éveque" were written with capital letters like in the original version. The abbreviations $\mathrm{M}$. were developed into $\mathrm{M}$ [onseigneur] or $\mathrm{M}$ [onsieur]. The title of the papal bull was written in italics.

Or.: Archivum Secretum Vaticanum, Additamenta Polonia, Additamenta 11 „Lettere diverse”, bez pag.

I.

Monseigneur

De Votre Excellence

À Varsovie le 20 Mars 1754

Monseigneur,

Je suis infiniment sensible à la part que Votre Excellence veut bien prendre à ma santé, qui s'affermit de jour en jour. Le Grand Marechal ${ }^{30}$ qui ne veut plus personellement du mal à $\mathrm{M}$ [onseigneur] l'auditeur ${ }^{31}$, n'est guère pour cela moins acharné contre l'état éclésiastique en général. Son etretien le plus favori c'est exagérer leur domination et leurs prétendues richesses. La protestation qu'il fit encore depuis peu avec une grande suite de petite noblesse est une preuve de ce que je viens de dire. Je sais qu'il a à présent honte, lui même, de la brochure $^{32}$, dont j'ai fait mention à Votre Excellence ${ }^{33}$. Mais il n'y a aucune espérance de la faire démordre de la poursuite d'une entreprise par laquelle il se flatte d'immortaliser son nom et d'acquérir la réputation de grand homme : car ce sont certainement ses idées. Je ne sais pas comment et où il fera ses Pâques ${ }^{34}$. Je prévois que, quand nous publierons comme à l'ordinaire Le Jeudi-Saint la bulle In Cona Domini ${ }^{35}$, il en sera de nouveau choqué.

J'ai déjà eu des nouvelles de Wilna que la lettre de Votre Excellence à $\mathrm{M}$ [onseigneur] l'Évêque du lieu ${ }^{36}$ en faveur des pauvres religieuses avait fait son effet. J'ai l'honneur de Vous renvoyer la réponse de ce prelat qui est fort bonne.

${ }^{30}$ Franciszek Bieliński (probably 1683-1766) - the grand crown marshall from 1742.

${ }^{31}$ Andreas Vincentius Buti - apostolic protonotary, the inspector of the nunciature in the Polish-Lithuanian Commonwealth in the years 1747-1754.

${ }^{32}$ Punkta propozycji przysłane przy liście JWJMci Pana Marszałka W. Koronnego sub datum 15 Mai z Otwocka do Prymasa oraz annotacje, [s.l.] 1753.

${ }^{33}$ Alberico Archinto (1698-1758) - the papal nuncio in the Polish-Lithuanian Commonwealth in the years 1746-1754.

${ }^{34}$ Easter - 14 April 1754.

${ }^{35}$ In Coena Domini (Przy stole Pańskim) - the papal bull traditionally announced by popes on Maundy Thursday; in Rome it commenced the Easter liturgy. It included, among others, a list of excommunications for heretics and enemies of the Church.

${ }^{36}$ Mikołaj Jan Zienkowicz (1670-1762) - the bishop of Vilnius 1730. 
J'espère que la lettre que Vous allez écrire Monseigneur, à $M$ [onseigneur] l'Évêque de Plock ${ }^{37}$ achèvera de le déterminer aux accommodements [?]. Il prétend la moitié proventuum triennalium certorum et incertorum. Ces revenus sont d'environ mille ducats par an et je crois qu'il se contentera de $500 \#^{38}$ qui sont environ le tiers de la prétension. Mais jusquà présent nous n’en sommes pas venus jusque-là.

J'ai indiqué à $\mathrm{M}$ [onseigneur] l'auditeur une voie sûre et inévitable [?] pour faire tenir la lettre du Pape à l'Évêque de Posnanie ${ }^{39}$. Il est sûr et notoire que ce prelat n’a jamais fait de visite dans son diocèse, à l'exception de la visite d'un hôpital de Varsovie qu'il avait commencée au commencement de son épiscopat, et qu'il n'a pas finie. Il est de même certain que la librairie étrangère ${ }^{40}$ établie à Varsovie dans le quartier appelé Marieville ${ }^{41}$ expose en vente toute sorte des livres, sans excepter ceux qui sont infiniment capables de nuire à la religion et aux bonnes mœurs. J'en ai averti ce prelat dès le commencement de son épiscopat. Il a voulu agir, mais voyant que le libraire était protégé par la cour il a abandonné l'affaire. Il [en] est sûr que parmi ses domestiques il y a des luteriens et en particulier un secrétaire allemand ${ }^{42}$ qui est un des principaux officiers de la maison. Je crois que parmi les bas domestiques il y a aussi des luteriens, mais je ne sais pas combien. Quand ce prelat faisait son séjour à Varsovie il y tenait ordinairement les ordinations dans les temps prescrits par l'église. Depuis qu'il n'y vient plus guère, et qu'il se tient sur ses terres en Grande Pologne, je crois qu'il ne les fait plus, d'autant quà Posnanie son official, qui est évêque in partibus $^{43}$ et son suffragant, peuvent aisement y suppléer à Varsovie on tâche aussi d’avoir un évêque pour les faire. M[onseigneur] le suffragant de Plock ${ }^{44}$, ou $\mathrm{M}$ [onseigneur] l'Évêque de Reaucour ${ }^{45}$ qui demeurent à Varsovie une grande partie d’années y suppléent le plus souvent. Quant à l'exercice public du luteranisme, je ne crois pas qu'on puisse en cesser le prelat avec fondement de l'avoir permis. Je connais sur cela ses principes : et si lon produit quelque sem-

${ }^{37}$ Józef Eustachy Szembek (died 1758) - the bishop of Płock 1753.

${ }^{38}$ \# - ducat called the red zloty, the golden coin minted in Poland since 1528.

${ }^{39}$ Teodor Czartoryski (1704-1768) - the bishop of Poznań from 1739.

${ }^{40}$ Bookshop of Krzysztof Bogumił Nicolai in Marywil.

${ }^{41}$ Marywil - the commercial centre set up upon the initiative of Queen Maria Kazimiera at the end of the $17^{\text {th }}$ century; in the $18^{\text {th }}$ century it constituted a major site of the activity of craftsmen and merchants.

${ }^{42}$ Unidentified person.

${ }^{43}$ Józef Tadeusz Kierski (died 1783) - from 1736 the titular bishop of Bolin and the suffragan bishop of Poznań.

${ }^{44}$ Marcin Załuski (1700-1768) - the auxiliary bishop of Płock in the years 1732-1765.

${ }^{45}$ Ludwik Riaucour (1700-1777) - the suffragan bishop of Lutsk from 1749. 
blable permission ou ordre dans la Basse Pologne (ce que je ne sais point) elle aura été [une] surprise à l'insu du prelat. M[onseigneur] Kral juge surrogat de l'officialité de Posnanie ${ }^{46}$ est un bon catolique : mais je ne crois pas qu'il soit à l'epreuve de l'intérêt. La permission ou ordre il y a quelques années à Varsovie pour le convoi funèbre du feu général Pepelman ${ }^{47}$ luterien, ne peut pas être attribuée à lévêque, car outre que cétaient proprement les honneurs militaires quon avait permis, M[onseigneur] Grzegorzewski ${ }^{48}$ alors official de Varsovie, qui avait reçu une somme d'argent pour cette permission, ce qui avait fait murmurer toute Varsovie, fut à cette occasion déposé de l'officialité.

Le Prince Évêque de Posnanie a des sentiments nobles ; le cœur bon, généreux, désintéressé : du goût pour les beaux arts et la musique, la peinture, l'architecture. Il aime s'amuser à la conversation, à la musique, au dessin, aux ameublemens, et quelque fois à la chasse. Ces amusements et les occupations économiques emportent la plus grande partie de son temps. Il lui en reste très peu pour les affaires éclesisstiques.

Voilà, Monseigneur, ce que je puis affirmer avec certitude - au sujet de ce prelat dont l'indolence ne fait à moi même une peine infinie.

J'espère que $\mathrm{M}$ [onseigneur] l'Évêque de Vlodimire ${ }^{49}$ profitera de bons avis que Votre Excellence lui a donnés et la disposition, où je sais que se trouvent les prêtres à qui on a fait souscrire en aveugle les griefs quon a entassés contre lui, ne fait croire que cette affaire ne fera plus de bruit.

Plus le temps du départ de Votre Excellence approche et plus je mafflige par l'idée que je naurai peut être jamais l'honneur de revoir un prelat que j’adore. Je me flatte cependant qu'Elle me conservera toujours l'honneur de sa bienveillance et qu'Elle voudra bien me recommnander à celle de son successeur ${ }^{50}$.

J'ai celui d'être avec un très respectueux et très inviolable attachement.

Le très humble et très obéissant Serviteur

Sliwicki ind[ignus] Prae[latus] de la C[ongrégation] de la Mission

Mille pardons de la malpropreté de cette lettre. Je n'ai pas le temps de la transcrire.

\footnotetext{
${ }^{46}$ Jan Krall - canon of Poznań, general inspector, a judge delegated with the powers of the vicar general.

${ }^{47}$ Carl Friedrich Pöppelmann (1697-1750) - architect, son of Matthäus Daniel Pöppelmann.

${ }^{48}$ Antoni Grzegorzewski - archdeacon, canon of the collegiate of St. John in Warsaw.

${ }^{49}$ Franciszek Antoni Kobielski (1679-1755) - bishop of Lutsk from 1739 (from the $15^{\text {th }}$ century the diocese of the town of Vladimir was combined with the diocese of Lutsk).

${ }^{50}$ Nicolaus Serra - the nuncio of the Polish-Lithuanian Commonwealth in the years $1754-1760$.
} 
II.

Monseigneur De Votre Excellence

À Varsovie le 6 avril 1754

Monseigneur,

Je nai plus d'espérance que $\mathrm{M}$ [onsieur] le Grand Marechal ${ }^{51}$ change de sentiments et de conduite à l'égard du clergé, ni qu'il se désiste de ses entreprises. Tout ce qu'on peut lui dire sur cette matière ne fait d'impression sur lui que pour un moment. Il reprend ensuite son système après avoir mal digéré. Il est à présent fort animé contre $\mathrm{M}$ [onseigneur] l'Évêque de Livonie ${ }^{52}$. Malgré la bonne mine [?] qu'il me fait toujours, il nous suscite des affaires et nous honore de sa persécution.

Le Prince Évêque de Posnanie m’a communiqué la copie du bref qu'il a reçue de Sa Sainteté, et celle de la réponse qu'il y a faite. J'ai l'honneur de joindre ici cette dernière. Je crois que tout ce que ce prelat y allègue est exactement vrai. Mais cela nempêche pas qu'il n'y ait encore bien des choses à désirer dan la conduite de son diocèse et de sa maison. Les principaux officiers, et une bonne partie des domestiques luteriens dans la maison d'un évêque, nédifient pas les bons catoliques. Cest quelque chose que davoir des grands vicaires vigilants et laborieux : mais il faudrait aussi faire quelque chose soi-même.

J'ai l'honneur d'être avec le plus profond respect et le plus inviolable attachement

\title{
Le très humble et trés obéissant Serviteur
}

Sliwicki ind[ignus] Prae[latus] de la C[ongrégation] de la Mission

\begin{abstract}
III.
Monseigneur De Votre Éminence

À Kraslau en Livonie le 27 Octobre 1757

Monseigneur,

Depuis la lettre, dont Votre Éminence ${ }^{53}$ ma honoré le 27 novembre 1756, je n'ai pas voulu l'impotuner des miennes, jusquà ce que je fusse en état de lui annoncer louverture actuelle du séminaire de Kraslau. Me voilà enfin sur les lieux, où j’ai eu la consolation de trouver M[onseigneur] l'Évêque de Smolensko ${ }^{54}$ chez M[onsieur] le comte Plater ${ }^{55}$. En attendant que ce seigneur puisse achever
\end{abstract}

${ }^{51}$ See fn. 30.

${ }^{52}$ Antoni Kazimierz Ostrowski (1713-1784) - bishop of Livonia in the years 1753-1763.

${ }^{53}$ On 5 April 1756 Archinto became cardinal; that is why, there is a change in the way he was addressed in the letter.

${ }^{54}$ Jerzy Mikołaj Hylzen (1692-1775) - bishop of Smolensk in the years 1745-1763.

${ }^{55}$ Konstanty Ludwik Plater (1722-1778) - the grand Lithuanian notary and the castellan of Polotsk in the years 1754-1758 
lédifice de brique qui sera solide et spacieux, il a fait bâtir un bon bâtiment de bois, suffisant pour l'habitation des missionnaires et des cleres. Il a lui même fondé quatre missionnaires. Leur ayant assigné pour cela le fond necessaire, une partie en biens-fonds et une partie en rente pecuniaire. M[onseigneur] l'Évêque de Livonie ${ }^{56}$ a de son côté fondé un professeur de théologie et quatre personnes gratuites des clercs: M[onseigneur] de Smolensko, outre un prêtre missionnaire, qui doit vaguer aux missions, a fondé de son côté un second professeur de théologie, et deux personnes gratuites des clercs, pour le service de son diocèse: de façon qu'il y a en tout sept Prêtres de la mission, et six clercs fondés.

Le nombre à la verité n'est pas encore complet, parce qu'il n'y a actuelllement dans la maison que trois misssionnaires dont l'un professeur en théologie et deux clercs choisis par M[onseigneur] l'Évêque de Smolensko et par $\mathrm{M}$ [onseigneur] le Grand Vicaire de Livonie ${ }^{57}$. Les autres, qui nont pas encore pu s'y rendre à cause de la distance des lieux, y vont arriver successivement et le séminaire est déjà actuellement ouvert. Nous sommnes en possession des fonds, et nous avons compté chaque pension annuelle des clercs sur le pied de 21 ducats par an. Le bâtiment de bois est suffisant pour contenir, quoique avec un peu d'incommodité, jusquà douze clercs outre les missionnaires. Aussi le nombre de six nest pas à beaucoup près suffisant, pour le service de deux diocèses. Le diocèse de Smolensko n’a à la vérité que trois paroisses principales, sans compter les églises affiliées: mais chacune de ces paroisses est plus grande pour létendue, que le diocèse entier de Varmie ${ }^{58}$. Une grande partie des habitants sont des Russes-unis; mais s'il y en a un grand nombre du rit latin, qui demandent du soin, et qui sont dispersés dans tous les coins. Tous les habitants de la Livonie et de la Curlande sont du rit latin, à lexcéption des luteriens, dont la secte est dominante en Curlande.

J'ai cru Monseigneur ce détail nécessaire pour mettre Votre Éminence au fait de cette affaire et en état de faire sentir à Sa Sainteté le besoin de ces deux vastes et pauvres diocèses, qui l'attendent aux effets de sa bonté paternelle.

Sans abuser plus longtemps de précieux moments de Votre Éminence je finis par les protestations du respect et de la reconnaissance infinie avec lesquelles je serai toute ma vie.

Le très humble, très obéissant et très obligé Servit. Sliwicki ind[ignus] Prae[latus] de la C[ongrégation] de la Mission

\footnotetext{
${ }^{56}$ See fn. 52.

${ }^{57}$ Franciszek Kazimierz Dowgiałło - auxiliary bishop of the Livonian diocese in the years $1744-1766$.

${ }^{58}$ The area of the diocese of Ermland [Warmia] was about $4700 \mathrm{~km}^{2}$. Comp. Stanisław LITAK, Kościół łaciński w Rzeczypospolitej około 1772 r., Lublin 1996, p. 45.
} 
Received 20 September 2017

Received in revised form 22 March 2018

Accepted 25 March 2018

Dr Joanna Orzet

Institute of History

Univeristy of Lodz

e-mail: joanna.orzel@interia.eu

ORCID ID: 0000-0001-8816-5157

Prof. dr hab. Stanisław Roszak

Institute of History and Archival Sciences

Nicolaus Copernicus University in Torun

e-mail:sroszak@umk.pl

ORCID ID: 0000-0002-6029-3672

\section{Letters of Piotr Hiacynt Śliwicki to the Papal Nuncio \\ Alberico Archinto from the Years 1754-1757 \\ in the Collections of the Vatican Archive}

\section{Summary}

Key words: correspondence of the $18^{\text {th }}$ century, the assembly of missionaries, the conflict about tithes of 1752-1753, Teodor Kazimierz Czartoryski, the seminary in Krasław, Protestant in Warsaw in the $18^{\text {th }}$ century, nunciature in the Polish-Lithuanian Commonwealth in the $18^{\text {th }}$ century

The article presents the hitherto unknown correspondence of the inspector of the general assembly of missionaries Piotr Hiacynt (Jacek) Śliwicki to the papal nuncio in the Polish-Lithuanian Commonwealth - Alberic Archinto, which is now preserved in the Vatican Archive. It includes three letters - two letters of 1754 and one of 1757, which are the evidence of the cooperation between the Church dignitaries. In the first letter Śliwicki referred to the conflict concerning the tithe, which lasted in the Polish-Lithuanian Commonwealth in the years 1752-1753. In both letters of 1754 he described to the papal nuncio the situation at the court of the bishop of Poznan Teodor Kazimierz Czartoryski, who was surrounded by Lutherans. In the letter of 1757 Sliwicki characterized the situation of Lazarists in Krasław, requesting some support (including financial help) from the Pope. The article was complemented by the source edition of the above-mentioned correspondence in the original language - French. 


\author{
Briefe von Piotr Hiacynt Śliwicki an den Nuntius \\ Alberico Archinto aus den Jahren 1754-1757 \\ in Den Sammlungen des Vatikanischen Archivs
}

\title{
Zusammenfassung
}

Schlüsselwörter: Briefwechsel aus dem 18. Jahrhundert, Lazaristen, Streit um den Zehnten 1752-1753, Teodor Kazimierz Czartoryski, Seminar in Kraslau, Protestanten in Warschau im 18. Jahrhundert, Nuntiatur in der Republik beider Nationen

Der Artikel befasst sich mit dem bisher unbekannten Briefwechsel des Generalvisitators der Lazaristen, Piotr Hiacynt (Jacek) Śliwicki, an den päpstlichen Nuntius in der Adelsrepublik, Alberico Archinto, der gegenwärtig im vatikanischen Archiv aufbewahrt wird. Die dort erhaltenen drei Briefe - zwei von 1754 und einer von 1757 zeugen von der Zusammenarbeit der kirchlichen Würdenträger. Im ersten Brief nahm Śliwicki Bezug auf einen Streit um den Kirchenzehnten, der sich in den Jahren 1753/54 in der Republik abspielte. In beiden Briefen aus dem Jahr 1754 berichtete er dem Nuntius von der Situation am Hof des Posener Bischofs Teodor Kazimierz Czartoryski, der sich mit Lutheranern umgab. Im Brief von 1757 beschrieb Śliwicki die Lage der Lazaristen in Kraslau und bat um deren personelle und materielle Verstärkung durch den Papst. Ergänzt wird der Artikel durch eine Quellenedition des Briefwechsels in der französischen Originalsprache.

\section{BIBLIOGRAPHY}

Acta Nuntiaturae Poloniae. vol. 1, Romae: Institutum Historicum Polonicum Romae Fundatio Lanckoroński, 1990.

Chmaj, Ludwik, ed. Historia Domus Varsaviensis Scholarum Piarum. Wrocław: Zakład Narodowy im. Ossolińskich, Wydawnictwo PAU, 1959.

Estreicher, Karol. Bibliografia polska, vol. 9: Spis chronologiczny. Kraków: Akademia Umiejętności, 1888.

Kitowicz, Jędrzej. Pamiętniki czyli Historia polska, oprac. Przemysława MatuszewSKA. Warszawa: Państwowy Instytut Wydawniczy, 1971.

Konopczyński, Władysław. “Teodor Kazimierz Czartoryski." http://www.ipsb.nina. gov.pl/a/biografia/teodor-kazimierz-czartoryski

Kriegseisen, Wojciech. Ewangelicy polscy i litewscy w epoce saskiej (1696-1763). Sytuacja prawna, organizacja i stosunki międzywyznaniowe. Warszawa: „Semper”, 1996.

Kuc-Czerep, Marta A. “Niemieckojęzyczni mieszkańcy osiemnastowiecznej Warszawy" [manuscript].

Litak, Stanisław. Kościół łaciński w Rzeczypospolitej około 1772 r. Lublin: Instytut Europy Środkowo-Wschodniej, 1996. 
Lustracja Dawidsona. In Źródła do dziejów Warszawy, vol. 1, wyd. Anna Berdecka, Janina Rutkowska, Anna Sucheni-Grabowska, Hanna Szwankowska, 387-460. Warszawa: Państwowe Wydawnictwo Naukowe, 1963.

Miranda, Salvador. The Cardinals of the Holy Roman Church. Biographical Dictionary. http://www2.fiu.edu/ mirandas/bios1756.htm\#Archinto

Pawlak, Wiesław. De eruditione comparanda in humaniorubus. Studia z dziejów erudycji humanistycznej w XVII wieku. Lublin: Wydawnictwo KUL, 2012.

Ratajewski, Jerzy. "Nicolai Krzysztof Bogumił." In Słownik pracowników książki polskiej, ed. Irena Treichel, 625. Warszawa-Łódź: Państwowe Wydawnictwo Naukowe, 1972.

Repertorium der diplomatischen Vertreter aller Länder, vol. 2. wyd. Friedrich Hausmann. Zürich: Fretz Wasmuth Verlag AG, 1950.

Smoleński, Władysław. Przewrót umysłowy w Polsce wieku XVIII. Studia historyczne, oprac. Andrzej Wierzbicki. Warszawa: Państwowy Instytut Wydawniczy, 1979.

Sulimierski, Filip, Chlebowski, Bronisław and Walewski, Władysław, eds. Słownik geograficzno-historyczny Królestwa Polskiego i innych krajów słowiańskich, vol. 4. Warszawa 1885.

Szymbor, W. “Trzy lata w życiu ks. Śliwickiego 1732-1734”. Roczniki Obydwóch Zgromadzeń Św. Wincentego a Paulo 15/4 (1909): 247-262.

Waniczkówna, Helena. Bieliński Franciszek, [w:] Polski słownik biograficzny, vol. 2, 47-50. Kraków: Polska Akademia Umiejętności, 1936.

Wieczorek, Agnieszka. Misje ludowe Zgromadzenia Księży Misjonarzy św. Wincentego a Paulo na terenie Rzeczypospolitej od połowy XVII do początku XIX wieku. Toruń: Wydawnictwo Naukowe UMK, 2014.

Zielińska, Zofia. "Śliwicki Piotr Hiacynt (Jacek)." In Polski słownik biograficzny, vol. 50/4, 586-591. Warszawa-Kraków: Instytut Historii PAN, Polska Akademia Umiejętności, 2015.

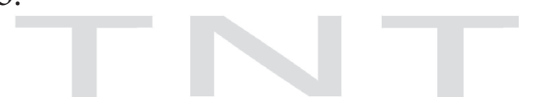

